УДК: 618.2-06:616.155.194-085:577.1

DOI: 10.24061/2413-4260.VIII.2.28.2018.15

\section{С.М. Ясніковська}

Вищий державний навчальний заклад України «Буковинський державний медичний університет» (Україна, м. Чернівці)

\author{
СУЧАСНІ ПІДХОДИ ДО ЛІКУВАННЯ

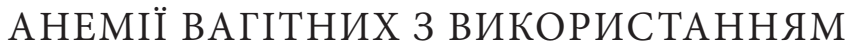 \\ ЕНЗИМІВ
}

\title{
Резюме
}

Bступ. Прогресивне зростання частоти анемії у вагітних за останнє десятиріччя (за даними ВООЗ від 20\% до 80\%) зумовлює актуальність даної патології. Анемія є фактором високого ризику розвитку гестозу, акушерських кровотеч, невиношування вагітності, перинатальної захворюваності і смертності, післяпологових гнійно-септичних захворювань. Дослідженнями останніх років доведена патогенетична участь синдрому ДВЗ крові в розвитку подібних ускладнень і необхідність корекиії гемостазу для їх профілактики і лікування.

мета. Дослідити ефективність запропонованого комплексу феротерапії в поєднанні з ензимами у вагітних з анемією, які проживають в Чернівеиькому регіоні на підставі виявлених змін в системі гемостазу.

Матеріал і методи. Ефективність запропонованого комплексного методу лікування анемії вагітних проаналізовано у 103 жінок мешканок Чернівецького регіону з анемією вагітних, яка не була обумовлена ні важкою екстрагенітальною, ні акушерською патологією (основна група). До числа обстежених входили жінки із середньо-тяжким ступенем анемії. Контрольну групу склали 65 жінок з гестаційною анемією, які отримували загальноприйняту комплексну терапію. Групи були статистично однорідними. Для очінки ефективності запропонованої терапії вивчали показники первинного та вторинного гемостазу, фібринолітичної активності крові, маркери ДВЗ-синдрому.

Результати дослідження. У роботі представлено результати клінічного застосування ензимів в комплексній терапії анемії вагітних, які свідчать про їх високу ефективність, що сприяли купуванню хронічного синдрому ДВЗ крові при вище зазначеній патології. Після запропонованого лікування у вагітних з анемією різного ступеню тяжкості достовірно подовжились час рекальцифікації (в 1,3 рази), активований парціальний тромбопластиновий час (в 1,5 рази). Протромбіновий час при легкій та середнього ступеню тяжкості анемії достовірно перевищував дані жінок з традиційною феротерапією відповідно в 1,56 i 1,57 рази (p<0,05). У вагітних із середньо-тяжким перебігом захворювання спостерігалася арифметична прогресія підвищення активності антитромбіну III. Кониентрація розчинних комплексів фібрин-мономеру в крові вагітних з анемією I ступеню зменшилась в 4,2 рази, при анемії II ступеню -- в 4 рази, а при анемії III ступеню - в 4,5 рази. Рівень продуктів деградації фібрину-фібриногену знизився в 8,7-10,2 рази, в той час як активність фактору Лакі-Лорана збільшувалася на 12,89\%, 14,36\% та 15,63\% відповідно. В результаті лікування достовірно знизилася частота акушерських ускладнень. Термін лікування дослідної групи був на 24-26\% (5-7 днів) менший від терміну вагітних контрольної групи. Зменшилась також кількість жінок із тяжкою формою захворювання.

Висновки. Результати застосування ензимів в комплексній терапії анемії вагітних свідчать про їх високу клінічну ефективність, які сприяють купуванню синдрому ДВЗ крові і зниженню частоти акушерських ускладнень при вище зазначеній патології.

Ключові слова: анемія вагітних; агрегантний стан крові; ензими.

\section{Вступ}

До числа проблем, які розвиваються на межі акушерства та гематології відноситься вивчення анемії у вагітних жінок. Важливість цієї проблеми пов'язана 3 ростом частоти даної патології (за даними МOO3 від 20\% до 80\%) [3, 5]. Анемія є фактором високого ризику розвитку гестозу, акушерських кровотеч, невиношування вагітності, перинатальної захворюванності і смертності, післяпологових гнійно-септичних захворювань $[1,2]$. Дослідженнями останніх років доведена патогенетична участь синдрому ДВЗ крові в розвитку подібних ускладнень і необхідність корекції гемостазу для їх профілактики і лікування $[4,6]$.

Метою роботи було вивчення ефективності запропонованого комплексу феротерапії в поєднанні з ензимами у вагітних 3 анемією, які проживають в Чернівецькому регіоні на підставі виявлених раніше змін в системі гемостазу.

\section{Матеріали та методи}

Ефективність запропонованого комплексного методу лікування анемії вагітних нами проаналізовано у 103 жінок мешканок Чернівецького регіону з анемією вагітних, яка не була обумовлена ні важкою екстрагенітальною, ні акушерською патологією (основна група). До числа обстежених входили жінки із середньо-тяжким ступенем анемії.

Контрольну групу склали 65 жінок з гестаційною анемією, які отримували загальноприйняту комплексну терапію. Групи були статистично однорідними.

Для оцінки ефективності запропонованої терапії ми вивчали показники первинного та вторинного гемостазу, фібринолітичної активності крові, маркери ДВ3-синдрому.

\section{Результати дослідження та їх обговорення}

Як показали наші дослідження, частота гестаційних анемій у вагітних, які мешкають в Чернівецькому регіоні досить висока і становить $46,8 \pm 2,1 \%$. В патогенезі пошкоджень репродуктивної функції жіночого організму при анемії суттєву роль відіграють порушення в системі регуля- 
ції агрегатного стану крові. Так, в II триместрі у вагітних 3 анемією ми виявили розвиток хронічного субклінічного синдрому ДВ3 крові, який був обумовлений активацією первинного гемостазу. Реалізація високого тромбоцитарного гемокоагуляційного потенціалу відбувалася за зниженням активності протизсідаючої системи і підвищенням низькоефективного неензиматичного фібринолізу, в той час, як ферментативні системи Хагеман-залежного фібринолізу пригнічувалися. В III триместрі високий ступінь анемізації вагітних призводив до ендотеліальних пошкоджень 3 прямою активацією одразу 3 механізмів зсідання крові - внутрішнього і зовнішнього шляхів гемокоагуляції та тромбоцитарно-судинного гемостазу [4, 7].

В зв'язку із виявленими нами в II і III триместрах вагітності порушеннями в системі гемостазу у жінок з гестаційною анемією виникла необхідність залучення до комплексу терапевтичних міроприємств препаратів, що впливають на агрегантний стан крові. Ми зупинили свій вибір на ензимному препараті, який складається 3 двох взаємодоповнюючих ферментів (бромелаїн 90 мг, трипсін 48 мг) та рутину рослинного походження (рутозід 100 мг). Препарат значно покращує мікроциркуляцію. Він здатен знижувати тромбоутворення і посилювати процеси фібринолізу, гальмує агрегацію тромбоцитів, впливає на адгезивні молекули і підвищує здатність еритроцитів змінювати свою форму.

Поряд $з$ цим в комплекс лікувальних заходів був включений розчин двохвалентного заліза для внутрішнього прийому та бджолина обніжка. Запропонований комплекс розпочинали застосовувати з 28-30 тижнів вагітності (при необхідності - в більш ранні або пізні терміни в залежності від тяжкості перебігу захворювання) протягом 2-3 тижнів 3 подальшим переходом на підтримуючі дози до родорозрішення.

Всі вагітні добре переносили запропоноване лікування, неприємних суб'єктивних почуттів ні у кого 3 них не було. Під впливом комплексної терапії із застосуванням ензимів позитивна динаміка клінічної симптоматики залізодефіциту спостерігалась у $30(83,3 \%)$ із 36 вагітних 3 першим ступенем анемії, у $38(77,6 \%)$ із 49 пацієнток 3 другим ступенем та у $9(50,0 \%)$ із 18 жінок з тяжким перебігом анемії. Спостерігалось покращення загального самопочуття у вигляді зникнення головокружіння та загальної слабкості. В той же час курс традиційної феротерапії привів до клінічного ефекту лише у $14(60,9 \%)$ iз 23 хворих 3 I ступенем, у $12(36,4 \%)$ із 33 вагітних з II ступенем i у $1(11,1 \%)$ із 9 пацієнток з тяжкою анемією.

Узагальнюючи вище наведені дані слід відмітити більш високу ефективність комплексної феротерапії і ензимів в порівнянні із застосуванням традиційної терапії препаратами заліза у вагітних із ЗДА, особливо, при важкому ступені залізодефіциту. Відсутність клінічної ефективності відмічено частіше у вагітних, які отримали лише курс традиційної феротерапії (34,8\% при I ступені, $54,5 \%$ при II-му та 77,8\% при III ступені ЗДА), ніж у пацієнток, яким проведено запропонований нами комплекс (16,7\% при I ступені, 18,3\% при II і 38,9\% при III ступені анеміï).
Було встановлено, що курс традиційної терапії в цілому сприятливо впливає на динаміку параметрів гемограми та сироваткового заліза, хоча ефективність даного курсу лікування значно нижча, ніж запропонованого нами комплексу. Якщо при традиційній феротерапії приріст гемоглобіну при I ступені анемії становив 22,12 г/л, при II-19,9 г/л, при III-19,02 г/л, то при застосуванні комплексного методу лікування дані показники відповідно становили 31,$64 ; 26,21$ та 36,23 г/л.

Приріст еритроцитів при комплексному лікуванні перевищував традиційне на 0,16 (х1012/л) при I ступені анемії, на 0,12 (х1012/л) при II та на 0,23 (х1012/л) при важкій анемії. Середня концентрація гемоглобіну зростала достовірно вище і суттєво відрізнялась після комплексної терапії: при легкому ступені анемії на 3,06\%, при середньому - на 3,67\%, при важкому на 2,11\%.

Традиційна терапія достовірно не впливала на збільшення кількості ретикулоцитів, тоді як використання ензимів збільшувало їх вміст в крові

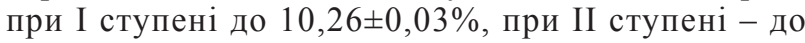
$11,74 \pm 0,03$, при III ступені - до $14,67 \pm 0,03 \%$.

Проведення запропонованої терапії призводило до нормалізації гемостазіологічних показників. Аналіз даних показав, що у вагітних 3 анемією різного ступеню важкості після отриманого лікування 3 використанням ензимів достовірно подовжились час рекальцифікації (в 1,3 рази), активований парціальний тромбопластиновий час (в 1,5 рази). Показники протромбінового часу також зросли порівняно з вихідними даними, але ступеню достовірності досягли тільки при анемії І сту-

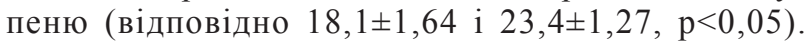
Тромбіновий час, який характеризує стан фібриногенезу, подовжувався у вагітних 3 анемією легкого і середнього ступеню важкості, які приймали запропоноване лікування і достовірно перевищував дані жінок $з$ традиційною феротерапією відповідно в 1,56 і 1,57 рази $(\mathrm{p}<0,05)$. Крім того, у вагітних з середньо-важким перебігом захворювання ми спостерігали арифметичну прогресію підвищення активності головного компоненту протизсідаючої системи - антитромбіну III.

Отже, можна зробити висновок, що у вагітних жінок з гестаційною анемією після феротерапії в комплексі з ензимами загальний гемокоагуляційний потенціал значно знизився.

До позитивних наслідків запропонованого курсу лікування ми віднесли і зниження активності первинного гемостазу, про що свідчило зниження індексу спонтанної агрегації тромбоцитів в 2,1 рази і процента адгезивних тромбоцитів в 2,65 рази $(\mathrm{p}<0,05)$.

Відображенням сприятливого впливу на гемостаз проведеної комплексної терапії слід вважати і зміни, відмічені при дослідженні маркерів ДВЗсиндрому.

Так, у вагітних 3 анемією І ступеню, які отримували комплексну феротерапію з ензимами концентрація в крові РКФМ зменшилась в 4,2 рази, при анемії II ступеню -- в 4 рази, а при анемії III ступеню - в 4,5 рази. Рівень ПДФ в сечі знизився в 8,7-10,2 рази, в той час як активність фактору Лакі-Лорана збільшувалася на 12,89\%, 14,36\% та $15,63 \%$ відповідно. 
Отже, можна зробити висновок, що запропонований комплекс лікувальних заходів призводить до купування хронічного ДВЗ-синдрому у жінок 3 гестаційною анемією.

Суттєвих змін в системі фібринолізу у досліджуваних жінок ми не виявили, окрім достовірного збільшення в 1,8 рази показників Хагеман-залежного фібринолізу. Збереження досить високих концентрацій фібриногену свідчило про відсутність ризику геморагічних ускладнень при подальшому перебігу вагітності та в пологах.

Аналіз клінічного перебігу вагітності та пологів показав, що корекція агрегатного стану крові запропонованим нами терапевтичним комплексом сприяла зменшенню частоти акушерських ускладнень. Достовірно меншою була кількість передчасних пологів $(1,4 \%$ проти $7,4 \%)$, ні в одному випадку не спостерігалось переношування вагітності, а також випадків передчасного відшарування плаценти. В той же час серед вагітних, які отримували традиційну терапію, ця патологія відмічена відповідно в 2,1 і 3,2\% випадків. Купування синдрому ДВЗ крові дозволило попередити патологічну крововтрату в пологах, в той час як в групі порівняння (без корекції гемостазу) така відмічена в 3 випадках, не дивлячись на проведення профілактичних заходів. Внутрішньоутробна гіпоксія плоду і асфіксія новонародженого відповід-

\section{Література}

1. Вдовиченко ЮП, Гопчук ОМ. Анемія вагітних - фактор ризику розвитку акушерської та перинатальної патології (огляд літератури). Здоровье женщины. 2016;3:62-5.

2. Долгіх АС, Михалко ЯО, Кутчак II. Вплив деяких факторів на ризик розвитку анемії під час вагітності. Здобутки клінічної і експериментальної медицини. 2016;2:50-2.

3. Жук СІ, Пехньо ТВ, Бикова ОГ. Залізодефіцитна анемія вагітних. Здоровье женщины. 2014;8:40-2.

4. Кравченко ОВ, Ясніковська СМ. Особливості гемостазу у вагітних міста та сільської місцевості за умов децидуально-трофобластичних порушень. Актуальні проблеми акушерства і гінекології, клінічної імунології та медичної генетики. 2008;15:102-4.

5. Кулаков ВИ, Серов ВН. Железодефицитная анемия и беременность. Здоровье женщины. 2015;9:21-4.

6. Ясніковська СМ. Нові підходи до корекції змін в системі гемостазу, що розвинулися на тлі невиношування вагітності. В Матеріали Міжнар. наук.-практ. конф. Актуальні досягнення медичних наукових досліджень в Україні та країнах ближнього зарубіжжя; 2014 Жов 3-4; Київ. Київ; 2014, с.86-90.

7. Ясніковська СМ. Характеристика системи гемостазу у вагітних 3 анеміями. In Materialy XI mezinarodni vedecko-prakticka konference Veda a technologie: krok do budoucnosti - 2015; 201527 Uno - 05 Bre; Praha. Praha; 2015, p.3-6. но в 2,5 і 5 разів рідше спостерігалась після проведення терапії з використанням ензимів. Не було також випадків перинатальної смертності, тоді як в групі порівняння цей показник склав 3,2\%о.

При анемії вагітних термін лікування дослідної групи був на 24-26\% (5-7 днів) менший від терміну лікування вагітних контрольної групи $(\mathrm{p}<0,05)$. Зменшилась також кількість жінок із важкою формою захворювання.

\section{Висновки}

Результати застосування ензимів в комплексній терапії анемії вагітних свідчать про їх високу клінічну ефективність, які сприяють купуванню синдрому ДВЗ крові і зниженню частоти акушерських ускладнень при вище зазначеній патології.

\section{Перспективи подальших досліджень}

Поглиблене вивчення змін в системі гемостазу у жінок з анеміями вагітності та корекція їх порушень матиме практичне значення щодо розробки комплексних методів лікування хронічного ДВ3синдрому на доклінічній стадії у даного контингенту вагітних та профілактики перинатальних ускладнень.

Конфлікт інтересів: Автор не заявляв будьякого конфлікту інтересів.

\section{References}

1. Vdovychenko YUP, Hopchuk OM. Anemiia vahitnykh faktor ryzyku rozvytku akushers'koi ta perynatal'noi patolohii (ohliad literatury) [Anaemia of pregnant - risk of obstetric and erinatological pathology factor]. Zdorov'e zhenshchiny. 2016;3:62-5 (in Ukrainian).

2. Dolhikh AS, Mykhalko YAO, Kutchak II. Vplyv deiakykh faktoriv na ryzyk rozvytku anemii pid chas vahitnosti [The influence of certain factors on the risk of anemia during pregnancy]. Zdobutky klinichnoi i eksperymental'noyi medytsyny. 2016;2:50-2 (in Ukrainian)

3. Zhuk SI, Pekhn'o TV, Bykova OH. Zalizodefitsytna anemiia vahitnykh [Iron deficiency anemia in pregnancy]. Zdorov'e zhenshchiny. 2014;8:40-2 (in Ukrainian).

4. Kravchenko OV, Yasnikovs'ka SM. Osoblyvosti hemostazu u vahitnykh mista ta sil's'koi mistsevosti za umov detsydual'notrofoblastychnykh porushen' [Features of hemostasis in pregnant city and rural areas under conditions of deciduous-trophoblastic violations]. Aktual'ni problemy akusherstva i hinekolohii, klinichnoi imunolohii ta medychnoi henetyky. 2008;15:102-4 (in Ukrainian).

5. Kulakov VI, Serov VN. Zhelezodefitsitnaya anemiya i beremennost' [Iron deficiency anemia and pregnancy]. Zdorov'e zhenshchiny. 2015;9:21-4 (in Russian).

6. Yasnikovska SM. Novi pidkhody do korektsii zmin v systemi hemostazu, shcho rozvynulysia na tli nevynoshuvannia vahitnosti [New approaches to the correction of changes in the system of hemostasis, developed in the context of miscarriage of pregnancy]. V: Materialy Mizhnar. nauk.-prakt. konf. Aktualni dosiahnennia medychnykh naukovykh doslidzhen v Ukraini ta krainakh blyzhnoho zarubizhzhia; 2014 Zhov 3-4; Kiev. Kiev; 2014, s.86-90 (in Ukrainian).

7. Yasnikovs'ka SM. Kharakterystyka systemy hemostazu u vahitnykh $\mathrm{z}$ anemiiamy [Characteristics of hemostasis in pregnant women with anemia]. In: Materialy XI International Science and Practice Conference Science and Technology: A Step to the Future -2015; 2015 27 Feb - 05 Mar; Praha. Praha; 2015, p.3-6 (in Ukrainian). 


\section{СОВРЕМЕННЫЕ ПОДХОДЫ К ЛЕЧЕНИЮ АНЕМИИ} БЕРЕМЕННЫХ С ИСПОЛЬЗОВАНИЕМ ЭНЗИМОВ

\section{С.М. Ясниковская}

\section{Высшее государственное образовательное учреж- дение Украины «Буковинский государственный медицинский университет» (г.Черновцы, Украина)}

\section{Резюме}

Введение. Прогрессивный рост частоты анемии у беременных за последнее десятилетие (за данными ВО3 от $20 \%$ до $80 \%$ ) обуславливает актуальность данной патологии. Анемия является фактором высокого риска развития гестоза, акушерских кровотечений, невынашивания беременности, перинатальной заболеваемости и смертности, послеродовых гнойно-септических осложнений. Исследованиями последних лет доказана патогенетическая роль синдрома ДВС крови в развитии подобных осложнений и необходимость коррекции гемостаза для их профилактики и лечения.

Цель. Исследовать эффективность предложенного комплекса ферротерапии в сочетании с энзимами у беременных с анемией, проживающих в Черновицком регионе на основании выявленных ранее изменений в системе гемостаза.

Материалы и методы. Эффективность предложенного комплексного метода лечения анемии беременных проанализирована у 103 женщин жительниц Черновицкого региона с анемией беременных, не обусловленной ни тяжелой экстрагенитальной, ни акушерской патологией (основная группа). К числу обследованных отнесены женщины со средне-тяжелой степенью анемии. Контрольную группу составили 65 женщин с гестационной анемией, получающие общепринятую комплексную терапию. Группы были статистически однородными. Для оценки эффективности предложенной терапии изучали показатели первичного и вторичного гемостаза, фибринолитической активности крови, маркеры ДВС-синдрома.

Результаты исследования. В работе представлены результаты клинического применения энзимов в комплексной терапии анемии беременных, свидетельствующие об их высокой эффективности, способствующих купированию хронического синдрома ДВС крови при выше указанной патологии. После предложеного лечения у беременных с анемией разной степени тяжести достоверно увеличились время рекальцификации (в 1,3 раза), активированное парциальное тромбопластиновое время (в 1,5 раза). Протромбиновое время при легкой и середней степени тяжести анемии достоверно превышало данные женщин 3 традиционной ферротерапией соответственно в 1,56 и 1,57 раза $(\mathrm{p}<0,05)$. У беременных с средне-тяжелым течением заболевания наблюдалась арифметическая прогрессия повышения активности антитромбина III. Концентрация растворимых комплексов фибрин-мономеpa в крови беременных с анемией I степени уменьшилась в 4,2 раза, при анемии II степени -- в 4 раза, а при анемии III степени - в 4,5 раза. Уровень продуктов деградации фибринафибриногена снизился в 8,7-10,2 раза, в то время как активность фактора Лаки-Лорана увеличилась на 12,89\%, 14,36\% и $15,63 \%$ соответственно. В результате лечения достоверно снизилась частота акушерских осложнений. Сроки лечения опытной группы были на 24-26\% (5-7 дней) меньше сроков беременных контрольной группы. Снизилось также количество женщин с тяжолой формой заболевания.

Выводы. Результаты применения энзимов в комплексной терапии анемии беременных свидетельствуют об их високой клинической эффективности, способствующие купированию синдрома ДВС крови и снижению частоты акушерских ослонений при выше указаной патологии.

Ключевые слова: анемия беременных; агрегантное состояние крови; энзимы.

\section{MODERN APPROACHES TO TREATMENT ANEMIA} OF PREGNANCY WITH USE ENZYMES

\section{S. Yasnikovska}

\author{
Higher State Educational \\ Establishment of Ukraine \\ «Bukovinian State Medical University» \\ (Chernivtsi, Ukraine)
}

\section{Summary}

Introduction. The progressive increase in the frequency of anemia in pregnant women over the last decade (for WHO data from $20 \%$ to $80 \%$ ) causes the urgency of this pathology. Anemia is a factor in the high risk of gestosis, obstetric hemorrhages, miscarriage, perinatal morbidity and mortality, postpartum septic complications. Studies of recent years have demonstrated the pathogenetic role the Coagulation Disorder of the blood in the development of such complications and the need for correction of hemostasis for their prevention and treatment.

Aim. To investigate the effectiveness of the proposed complex of ferrotherapy in combination with enzymes in pregnant women with anemia living in the Chernivtsi region on the basis of previously revealed changes in the hemostasis system.

Materials and methods. Efficacy of the proposed complex method for the treatment of anemia in pregnant women was analyzed in 103 female residents of the Chernivtsi region with anemia of pregnant women, which was not caused by severe extragenital or obstetric pathology (main group). Among those surveyed were women with a moderate to severe anemia. The control group consisted of 65 women with gestational anemia who received the standard complex therapy. The groups were statistically homogeneous. To assess the effectiveness of the proposed therapy, primary and secondary hemostasis, fibrinolytic activity of blood, markers of Coagulation Disorder were studied.

Research results. The paper presents the results of the clinical use of phlogenzime in the complex therapy of anemia of pregnant women, which testifies to the high efficiency of enzymes that contribute to the relief of the chronic Coagulation Disorder of the blood in the above pathology. After the proposed treatment in pregnant women with anemia of varying severity, the recalcification time (by 1.3 times), activated partial thromboplastin time (by a factor of 1.5) significantly increased. Prothrombin time in mild and moderate severity of anemia significantly exceeded the data of women with traditional ferrotherapy, respectively, by 1.56 and 1.57 times $(p<0.05)$. In pregnant women with a medium-severe course of the disease, an arithmetic progression of an increase in the activity of antithrombin III was observed. The concentration of soluble complexes of fibrin-monomer in the blood of pregnant women with anemia of the I degree decreased 4.2 times, in case of anemia of the 2 nd degree - 4 times, and in case of anemia of the third degree - by 4.5 times. The level of degradation products of fibrin-fibrinogen decreased by 8.7-10.2 times, while the activity of the Laki-Laurent factor increased by $12.89 \%, 14.36 \%$ and $15.63 \%$, respectively. As a result of treatment, the incidence of obstetric complications significantly decreased. The duration of treatment of the experimental group was $24-26 \%$ (5-7 days) less than the duration of the pregnant control group. The number of women with a severe form of the disease also decreased.

Conclusions. The results of the use of enzymes in the complex therapy of anemia of pregnant women testify to their high clinical efficacy, contributing to the relief of the Coagulation Disorder of the blood and the reduction in the frequency of obstetric anesthesia with the above pathology.

Keywords: Anemia of Pregnant Women; Coagulation Disorder of Blood, Enzymes.. 


\section{Контактна інформація:}

Ясніковська Світлана Михайлівна -

к.мед.н., доцент кафедри акушерства

гінекології та перинатології Вищого дер-

жавного навчального закладу України

«Буковинський державний медичний університет» (м. Чернівці, Україна).

Контактна адреса: площа Театральна,

2, м. Чернівці, 58002, Україна.

Контактний телефон: +38 (097) 4713426

e-mail: jasnikovska.svitlana@bsmu.edu.ua

ORCID: http://orcid.org/0000-0002-5826-3845

ResearcherID: E-2092-2017
Контактная информация:

Ясниковская Светлана Михайловна -

к.м.Н., доцент кафедры акушерства, гинекологии и перинатологии Высшего государственного учебного заведения Украины «Буковинский государственный медицинский университет» (г. Черновцы, Украина).

Контактный адрес: площадь Театральная,

2, Черновцы, 58002, Украина.

Контактный телефон: +38 (097) 4713426

e-mail: jasnikovska.svitlana@bsmu.edu.ua

ORCID: http://orcid.org/0000-0002-5826-3845

ResearcherID: E-2092-2017

(C) S.Yasnikovska, 2018

\section{Contact Information:}

Svitlana Yasnikovska - $\mathrm{PhD}$, Assistant Professor of the Department of Obstetrics, Gynecology and Perinatology of the Higher State Educational Establishment of Ukraine "Bukovinian State Medical University» (Chernivtsi, Ukraine).

Contact address: Teatralna Square, 2, Chernivtsi, 58002, Ukraine.

Phone: +38 (097) 4713426.

e-mail: jasnikovska.svitlana@bsmu.edu.ua

ORCID: http://orcid.org/0000-0002-5826-3845

ResearcherID: E-2092-2017

Надійшло до редакції 14.03.2018 Підписано до друку 15.06.2018 